\title{
Argumenta OECONOMICA
}

$1(46) \cdot 2021$

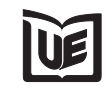

Publishing House of Wroclaw University of Economics and Business Wroclaw 2021 


\title{
Editors
}

Ewa Knichnicka

Anita Makowska

Verified by Elżbieta Macauley,

Tim Macauley and Ewa Kania

Graphic design: Maciej Szłapka

Argumenta Oeconomica is covered in Clarivate Analytics services:

\author{
Social Sciences Citation Index ${ }^{\circledR}$ \\ Social Scisearch ${ }^{\circledR}$ \\ Journal Citation Reports/ Social Sciences Edition \\ and in Elsevier service Scopus
}

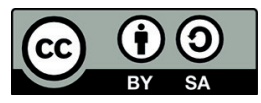

This work is licensed under the Creative Commons Attribution-ShareAlike 4.0 International License.

To view a copy of this license, visit http://creativecommons.org/licenses/by-sa/4.0/ 


\section{TABLE OF CONTENTS}

\section{ARTICLES}

Marta Małecka

INDUSTRY STANDARD AND ECONOMETRIC STANDARD: THE SEARCH FOR POWERFUL APPROACH TO EVALUATE VaR MODELS ...

Xesús Pereira López, Małgorzata Anna Węrzyńska,

Melchor Fernández Fernández

METHODOLOGICAL CONTRIBUTION TO THE DETECTION OF BACKWARD LINKAGES BETWEEN SECTORS OF THE ECONOMY .....

Ana Mugoša, Saša Popović

DEVIATION FROM TARGET CAPITAL STRUCTURE AS A FACTOR OF ACQUISITION DECISIONS IN EUROPEAN DEVELOPED MARKETS....

Maja Bacovic

TOTAL FACTOR PRODUCTIVITY GROWTH IN UPPER MIDDLEINCOME BALKAN COUNTRIES FROM 2000-2017, TOTAL ECONOMY AND SECTORAL APPROACH: THE GROWTH ACCOUNTING METHOD

Dmytro Osiichuk

PERFORMANCE ASIDE... THE ORGANIZATIONAL AND DIRECTORLEVEL DETERMINANTS OF BOARDS' COMPENSATION....

Tomasz Schabek, Lucas Ayres Barreira de Campos Barros

THE MARKET, MACROECONOMIC, AND BEHAVIOURAL FACTORS IN EMERGING MARKETS: THE CASE OF POLAND

Tomasz Serwach, Piotr Gabrielczak

DOES EUROPEAN INTEGRATION MAKE EXPORTS MORE COMPLEX?

Yechang Yin, Li Sheng

THEORIZING ABOUT GLOBAL IMBALANCES: AN INEQUALITY PERSPECTIVE 
Muhammad Jam e Kausar Ali Asghar, Zeshan Anwar, Muhammad Usman, Hamad Khan

BETTER CORPORATE GOVERNANCE LEADS TO BETTER PERFORMANCE: EVIDENCE FROM ASIAN COUNTRIES

Michat Comporek

ESTIMATING ACCRUAL-BASED MODELS IN POLAND: THE TIME SERIES DATA APPROACH AND THE CROSS-SECTIONAL DATA APPROACH

Cristina Gabriela Cosmulese, Aurel Burciu, Marian Socoliuc,

Marius Ciubotariu, Rozalia Kicsi, Veronica Grosu

OPTIMIZATION MODEL FOR SUSTAINABLE FOOD SUPPLY BASED

ON CONSUMER BEHAVIOUR TYPOLOGY. THE CASE OF THE CHISINAU URBAN AREA

\section{REVIEWS AND NOTES}

Elżbieta Sobczak (ed.): REGIONALNE I LOKALNE UWARUNKOWANIA ROZWOJU GOSPODARKI POLSKI [REGIONAL AND LOCAL DETERMINANTS OF POLAND'S ECONOMIC DEVELOPMENT] (Artur Myna)

Adam Kubów (ed.): WYZWANIA POLITYKI SPOŁECZNEJ. WYBRANE ASPEKTY [CHALLENGES FOR SOCIAL POLICY. SELECTED ASPECTS] (Marta Makuch) 